\title{
FRP-Retrofitting RC Bridges for Stabilization in Earthquakes
}

\author{
Kenneth C Crawford ${ }^{1 *}$ and Stojan Krsteski ${ }^{2}$ \\ ${ }^{1}$ Institute for Bridge Reinforcement and Rehabilitation, USA \\ ${ }^{2}$ Financial Economics, Wabash College, USA
}

Received: 眥 February 26, 2018; Published: 制 March 07, 2018

*Corresponding author: Kenneth C Crawford, Institute for Bridge Reinforcement and Rehabilitation, USA, Tel Ph: 661-247-7600;

Email: ken.crawford@ibrr.org

\begin{abstract}
The purpose of this abbreviated paper is to analyze the applicability of FRP (fiber-reinforced polymer)-strengthening systems for retrofitting RC (reinforced-concrete) highway bridges to stabilize structural members under earthquake conditions. Three earthquakes in California, with multiple bridge failures, drove the requirement to improve bridge design and methods of structurally upgrading critical bridge components to withstand impacts of earth tremors. Retrofitting RC bridges by encasing and strengthening bridge bents with FRP-systems provides an effective method of mitigating the impacts of earthquake loading. This analysis considers types of retrofitting applications on bridge bents and the advantages of FRP systems to increase structural member axial capacity and ductility in columns and beams.
\end{abstract}

Keywords: Bridges; Columns; Beams; FRP systems; Earthquakes

\section{Introduction}

Transportation infrastructure destruction in earthquakes can be extensive, particularly when older RC bridges are not designed to current earthquake codes. Bridges constructed before the 1970's, in Europe, Asia, and the USA, and not retrofitted, have a potential risk of failure, even in moderate earthquakes. Recent California earthquakes (last 45 years) caused multiple modes of failure in RC bridge critical structural elements. The primary causes of bridge collapses were insufficient ductility in the bridge columns, inadequate lap-splice length in the potential plastic hinge regions, and insufficient transverse reinforcement. Retrofitting existing RC bridge bents (columns and beams) is an efficient and cost effective rehabilitation technique to improve seismic performance.

Major techniques for structural rehabilitation of RC bridges include encasing columns and beam column joints using steel, FRP, RC jackets, and adding new steel bracing structural elements [1]. Retrofitting circular/rectangular bridge columns by adding cylindrical or elliptical steel jackets in the plastic hinge region is an effective measure to enhance shear strength and flexural ductility. As an alternative to steel jackets, advanced FRP composite material have been developed for retrofitting concrete columns, resulting in significantly improved hysteretic response and increased ductility.
The unique properties of carbon FRP (CFRP) with its high strength, low weight, and ease of application provide an ideal material for strengthening RC bridge columns and beams for gravity-load designed multi-column bridge bents. Retrofitting older highway bridges to mitigate loss of service ability in seismic events is a costeffective option compared to the high cost of bridge replacement. Three earthquakes produced far reaching changes in California seismic codes and bridge design philosophy.

\section{Sylmar earthquake}

Occurred in southern California with a magnitude 6.6, lasting 12 seconds at a depth of $13 \mathrm{~km}$. Thrust faulting ruptured a $19 \mathrm{~km}$ segment of the San Fernando fault with a maximum slip of 2 meters, causing twelve overpass bridges to fail falling onto freeways below. Damage to bridge structures varied from minor cracking to complete loss of bridge sections.

\section{Loma prieta Earthquake}

Occurred 60 miles south of San Francisco, magnitude of 6.9, lasting 15 seconds, at depth of $10 \mathrm{~km}$, with significant vertical displacement. Major transportation structures suffered catastrophic failures from failed support columns. 


\section{Northridge Earthquake}

Occurredin the north-central San Fernando Valley, Los Angeles, magnitude of 6.7, with seven collapsed freeway overpasses, causing $\$ 50$ billion in damage and 57 deaths. Bridges collapsed due to column failure from inadequate shear design, lack of flexural capacity and buckling of the compression reinforcement, (Figure 1) High vertical acceleration caused column flexure/shear failures. The rate of vertical acceleration was the highest ever recorded in North America.

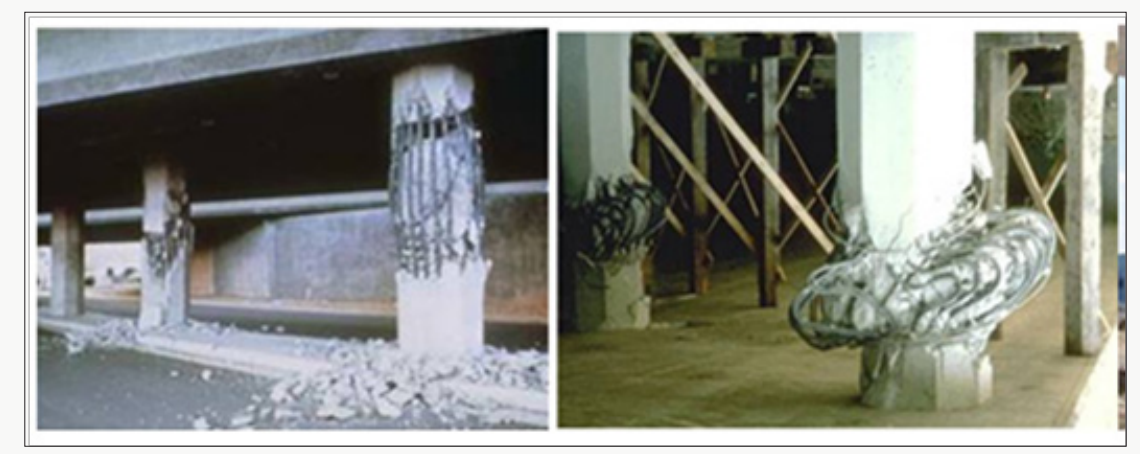

Figure 1: Failed highway bridge columns.

\section{Materials and Methods}

Following the 1994 Northridge earthquake Cal Trans (California Dept of Transportation) established the Seismic Advisory Board (SAB) making substantial efforts to improve bridge seismic structural codes. In their seismic design criteria the SAB specified ductile/seismic-critical RC bridge members sustaining damage during a seismic event cannot collapse or lose structural integrity. Since 1994, substantial efforts were made to retrofit RC highway bridges with a variety of structural improvements. This paper analyzes the application of CFRP composite material to strengthen and stabilize bridge bents and foundations for seismic loading.

\section{Materials}

The CFRP composite material for jacketing RC bridge columns and beams to strengthen columns or girders for shear, reinforced concrete slabs in flexure, and joints for external cap/column connections, has significant benefits over steel jacketing. The CFRP sheet material is a carbon fiber/epoxy resin composite with 48,000 unidirectional carbon fibers per tow with 6.5 tons per $25.4 \mathrm{~mm}$. CFRP design parameters have a modulus of elasticity of $65 \mathrm{GPa}$, a tensile strength of $628 \mathrm{MPa}$, ultimate axial strain of $10 \mathrm{~mm} / \mathrm{m}$, and a layer thickness of $1.32 \mathrm{~mm}$ [2].

\section{Methods}

In retrofitting $\mathrm{RC}$ bridge bents it is necessary to develop a higher base shear and moment capacity than the existing foundation and pile cap system. The performance-based design procedure includes a nonlinear static analysis of the bridge bent to determine column CFRP jacket thickness for plastic hinge confinement, shear strengthening, and lap splice clamping. The design increases displacement ductility of the bridge bent (column beam cap) developing a higher base shear and moment capacity than the existing foundation and pile cap system. The RC beam connecting pile cap completes the tension and compression load path, increasing shear and flexural capacity of the foundation. The CFRP jacket in the bent T-joints, (Figure 2) consists of three elements: (a) diagonal FRP composite sheets for resisting diagonal tension, (b) FRP composite sheets in the direction of the beam cap axis for shear strengthening and increased flexural capacity, and (c) U-straps anchoring the longitudinal column bars providing additional flexural strength [2]. An additional retrofit method involves application of near-surface-mounted (NSM) CFRP rods anchored into column footings to increase flexural strengthening [3].

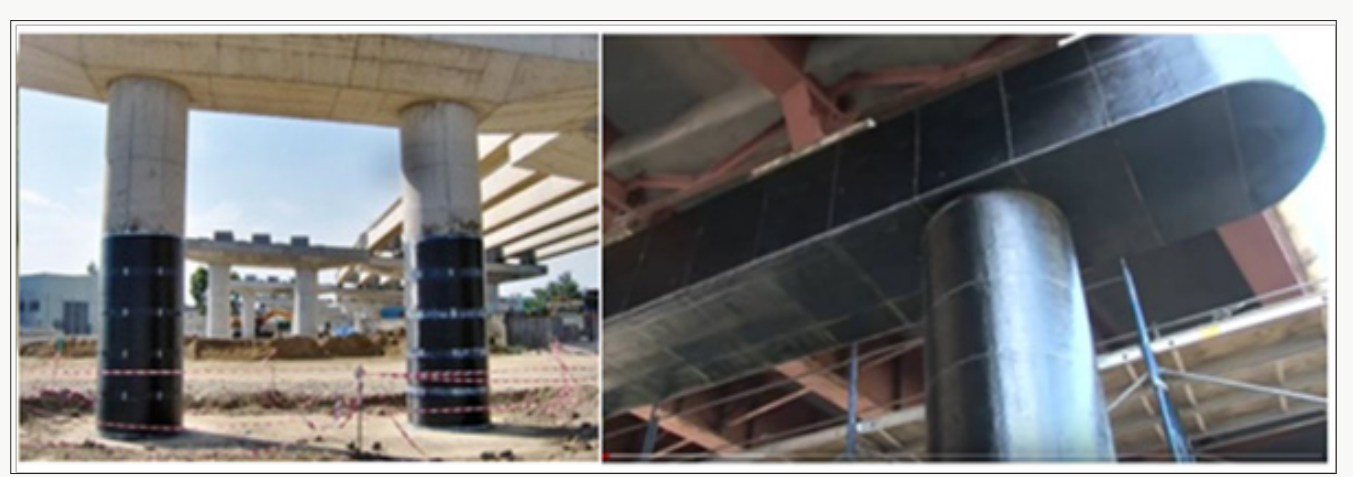

Figure 2: CFRP wrapped bridge columns and bent. 


\section{Results and Observations}

In-situ experiments of multi-column bridge bents demonstrate an external CFRP composite seismic retrofit combined with a retrofit of the foundation providing increased ductility and seismic performance. The applied CFRP layers strengthen the column lap providing additional clamping capacity, adding external stiffness to the lap splice, transferring the plastic hinge above the lap splice elevation, providing additional shear capacity, flexural stiffness, and confinement. With increased flexural stiffness the base moment demands are transferred more efficiently into the bent pile foundation system [1].

\section{Conclusion}

The bridge retrofitting program after the 1971 earthquake provided a new basis for designing and constructing highway bridges to survive moderate to major earthquakes. Cal Trans made significant changes in designing and constructing highway bridges. Retrofitting bridge bents with CFRP composites prove valuable in reducing column flexure/shear failure. FRP-structural systems applied to RC bridge bents provide reliable strengthening to mitigate the impact of earthquake loading and sustain bridge serviceability.

\section{References}

1. Mori M, Alam S (2010) Seismic performance evaluation of retrofitted multi-column bridge bents. Joint Conference on Advances in Bridge Engineering, Bangladesh.

2. Pantelides C, Duffin J, Reaveley L (2004) Design of FRP Jackets for Seismic Strengthening of Bridge T-Joints. $13^{\text {th }}$ World Conference on Earthquake Engineering, Canada.

3. Alkhrdaji, T Nanni A (2000) Flexural Strengthening of Bridge Piers Using FRP Composites. ASCE Structural Congress, USA.

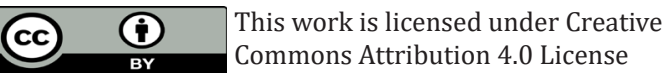

To Submit Your Article Click Here:

Submit Article

DOI: 10.32474 /TCEIA.2018.01.000120

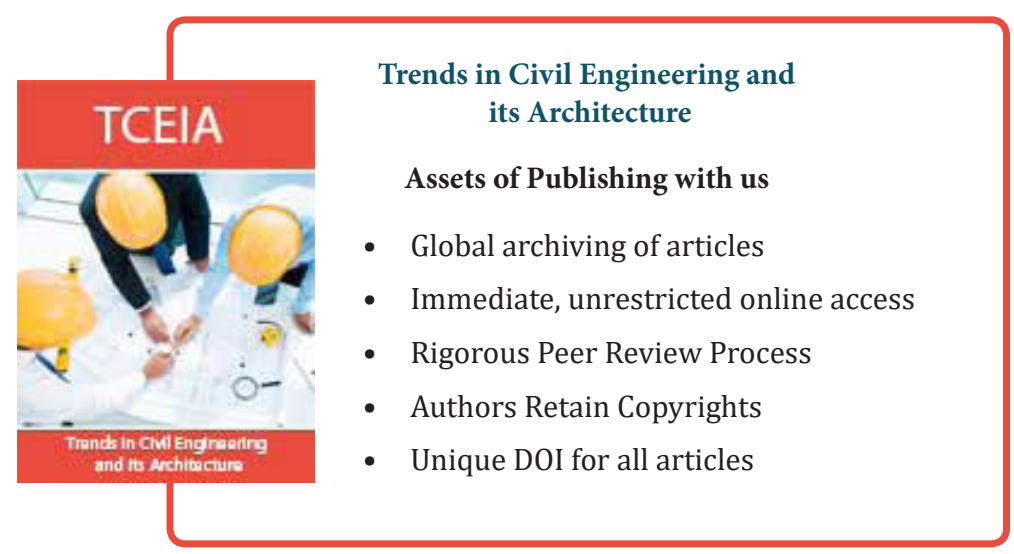

